\title{
Analysis Of The Influence Path Of Guiyang Big Data Expo On Regional Economic DevelopmentS
}

\author{
Qing LI $^{1}$ \\ ${ }^{1}$ Guizhou Minzu University, Guiyang, China
}

\begin{abstract}
Exhibition industry is an important part of modern service industry, and exhibition economy can play a strong driving role in regional and industrial development. At the same time, the exhibition economy is different from other industries. In addition to the direct benefits generated by the exhibition itself, the exhibition industry has a strong pulling effect on the regional economic development due to its strong clustering characteristics. The Big Data Expo is an important platform for the development of national big data industry, through the development of Guiyang Digital Expo, this paper proposes to promote the optimization and upgrading of regional industrial structure by cultivating exhibition industry chain, promoting the evolution of regional economic development path and enhancing regional comprehensive competitiveness, so as to realize the driving effect of exhibition industry and exhibition economy on regional economic development.
\end{abstract}

\section{Introduction to The Big Data Expo}

The international big data industry expo, referred to as the Big Data Expo, is sponsored by the National Development and Reform Commission, the Ministry of Industry and Information Technology, cyberspace Administration of China and the People's Government of Guizhou Province. Since its inception in 2015, the Big Data Expo has been successfully held for five consecutive years, and officially upgraded to a national exhibition in 2017. As the world's first big data theme expo, with its leading advantages in internationalization, specialization and marketization, The Big Data Expo has become the bellwether of global big data development and the most international and authoritative platform for the industry to exchange achievements. The first Guiyang International Big Data Industry Expo was held in Guiyang International Conference and Exhibition Center in 2015, attracting 380 exhibitors with an exhibition area of 54,412 square meters and over 60,000 visitors. More than 30 enterprises have reached cooperation intention with Guiyang city, and signed nearly 40 projects with an investment amount of more than 20 billion yuan. With the theme of "Innovative Development · Digital Future", the 2019 Big Data Expo opened as scheduled, and guests from 55 countries and regions discussed the development and cooperation of big data industry. The expo attracted 448 exhibitors with 60,000 square meters of exhibition area and over 120,000 visitors. During the expo, 92 activities were organized and arranged, including conferences, forums and exhibitions, which also attracted more attention from countries along the the Belt and Road Initiative. A total of 30 countries and regions along the the Belt and Road Initiative participated in the expo. The scope of participating countries has been greatly expanded, making "internationalization" the development trend and highlight of the Big Data Expo.

As the world's first big data theme exposition, the past five years, the Big Data Expo has always been adhering to the "global vision, the national level, the industrial perspective, enterprise position" office concept, adhere to the "delicate, exquisite, perfection" and "safety, comprehensive" standard of office will, every successful, brilliant, constantly refresh the guest level, organization form, attending size pieces, attending results record. The Expo highlights the lofty cultural mission and provides an important platform for economic development cooperation between countries and regions. The Big Data Expo will not only help to greatly enhance the international image and influence of Guiyang, promote China's exhibition to the international stage, but also help to promote the construction of infrastructure in Guiyang and southwest region, and will also have a positive impact on the accumulation of exhibition experience and the cultivation of exhibition talents [1].

\section{The path analysis of the influence of the Big Data Expo on regional economy}

From the perspective of regional economics, the exhibition will produce a huge driving effect, promote the rapid development of exhibition industry, tourism and related industries in Guiyang, Guizhou province and even the southwest region, and accelerate the process of regional economic development. It is the core content of exhibition economy that Guiyang gains direct or indirect economic and social benefits by holding large-scale, 
multi-level and multi-category exhibition activities. However, how exhibition industry and exhibition economy produce economic and social effects, and to what extent these effects are, it is necessary to analyze the path that exhibition economy drives regional economic development. As an important platform for the development of China's big data industry, the Big Data Expo can promote the upgrading of regional industrial structure to achieve its driving effect on regional economic development.

\subsection{The Big Data Expo will contribute to the formation of exhibition industry chain}

- The Expo can directly drive the development of Guiyang's cultural industry and traditional tourism industry, and cultivate the emerging exhibition tourism. Guizhou is a big tourism province, karst landscape, ethnic minorities and other tourism resources are particularly rich, the Big Data Expo closely conforms to the development spirit of "peace and cooperation, openness and inclusiveness, mutual learning and mutual benefit", and will greatly promote the development of cultural industry and tourism industry in the region [2]. Taking the Big Data Expo 2019 as an example, under the theme of "Innovation, Development, Digital Future", the Expo will hold a number of professional forums around the five major areas of technology innovation, data security, digital economy, integrated development, and cooperation and exchange. Also around "one exhibition, one release, contest and a series of activities" organized a variety of activities, increase the diversity of the expo characteristics, but also improve the quality of the exhibition.



Fig1. a. Exhibition industry chain structure pattern diagram

- The exhibition industry has great relevance and extroversion. In addition to its direct impact on the cultural industry and tourism industry, the Big Data Expo can also drive the common development and benefit sharing of related industries and form the exhibition industry chain. Exhibition industry and exhibition economy can increase the flow of urban personnel, stimulate the consumption demand of urban goods and services, drive the development of transportation, tourism, shopping, catering and accommodation industries, and form a longer consumption chain. At the same time, the conference and exhibition industry usually includes commodity exhibition, conference, visit and investigation, news communication and other related activities, thus driving the follow-up of related industries such as advertising, printing, tourism and telecommunication. In the long run, the contribution of conference and exhibition industry and exhibition economy to urban economic development will continue to increase, reduce the city's reliance on resource-consuming industries, and improve the sustainable development capacity of urban economy. At present, Guiyang's exhibition industry has formed a certain scale, but there is an obvious gap between Guiyang and Beijing, Shanghai and Guangzhou, cities with developed exhibition economy. From the perspective of the industrial chain, there are also many problems, such as the supporting problems of each link of the upstream and downstream industry. Therefore, it is particularly important to integrate the whole exhibition industry chain with the opportunity of the Big Data Expo.

- Promote the cooperation and exchange of scientific and technological knowledge and innovative thinking. The Big Data Expo is not only an important platform for dialogue between civilizations and cultural exchanges, but also a window for the exchange of economic, technological and advanced development concepts. The participants took the Big Data Expo as a platform for innovative cooperation to establish a long-term mechanism of mutual benefit and win-win cooperation in various forms and with rich contents. Meanwhile, the platform was built to promote regional higher education cooperation, which helped to pool knowledge and wisdom and cultivate various talents including professional exhibition personnel [3]. In 2018, the College of Big Data Statistics jointly run by the National Bureau of Statistics and Guizhou Provincial Government was established in Guizhou University of Finance and Economics. It is committed to deepening the integrated development of big data and statistics, serving the national big data strategy, and cultivating innovative and compound high-end talents in big data statistics. Meanwhile, eight universities in the province have been approved by the Ministry of Education to offer "Data Science and Big data Technology". The province has initially formed a big data talent training system from social training, secondary vocational and vocational colleges to undergraduate and graduate students. The Fair not only reflects the education level of countries and regions, realizes the linkage between industry and learning, and further promotes the sharing of science and technology education resources among universities, research institutes and 
enterprises. It will cultivate more big data professionals for Guizhou and the whole country, and contribute to the cultivation of high-level talents and the prosperity of regional economic development.

\subsection{The Big Data Expo can promote the evolution of regional economic development path}

- The Big Data Expo will enhance the city's visibility and the core competitiveness of the city. The operation mechanism and system of economic activities in specific regional space constitute regional economy. As an important part of modern service industry, conference and exhibition industry is of great significance to the flow of elements in the region. The exhibition industry is the core link connecting the secondary industry and the tertiary industry. It is the bridge and link connecting producers and consumers. It has a strong agglomeration effect in demand and supply regulation, driving the development of emerging industries and driving investment [4]. On the one hand, by reducing the circulation of economic factors, conference and exhibition industry and exhibition economy can reduce the supply cost and transaction cost of regional economic factors. On the other hand, the conference and exhibition industry and the exhibition economy can gather a large number of economic resources such as commodities, capital and information to provide a platform for the efficient integration of various related industries and create a good external environment. In promoting the demand and supply of effective docking, smooth flow channel in the process of economic elements, convention and exhibition industry and exhibition economy to play a strong role in driving regional economic development, regional industrial structure along the laborintensive to capital-intensive and intensive development path of evolution, so as to realize the regional industrial structure optimization and upgrading. With the continuous development of exhibition industry and exhibition economy, urban economy will gradually reduce its dependence on resource-consuming consumer industries, and the sustainable development ability of urban economy will be improved.

- The Big Data Expo will improve the level of urbanization management. Convention and exhibition industry and exhibition economy drive ton of urban infrastructure, promote the urban development of the indispensable puhe development of urban convention and exhibition industry and its related industries, can drive the constructiblicity and marketing. From the beginning of the preparation of the exhibition to the end of the exhibition, the Big Data Expo, through the market operation, fully mobilize the urban infrastructure services, information resources, public management services, promote the construction of Guiyang city hardware and software, and achieve a great improvement in the level of urban management and management benefits. At present, the Big Data Expo has developed into an important and national exhibition activities, to ensure the smooth progress of the exhibition, it is necessary to go to the city management departments of cooperation, efficient promotion. The development of exhibition economy is an important way to promote the development strategy of leapfrog transformation of urban functions. In this process, the organizers of the Fair have improved their emergency response ability and accumulated experience in urban management. A graph within a graph is an "inset", not an "insert". The word alternatively is preferred to the word "alternately" (unless you really mean something that alternates).

- The Big Data Expo will cultivate high-level international exhibition talents and establish a professional big data talent reserve. Taking Guiyang Big Data Expo as an opportunity, we should strengthen the learning and training of exhibition professionals and make a good training plan for it professionals in advance. We should lay the foundation for the digitalized and innovative development of conference and exhibition industry and exhibition economy, and cultivate a group of professional exhibition talents who are proficient in professional knowledge and provide high-quality and efficient services. We will build a platform for sharing knowledge and experience, and promote exchanges between the government, academia, industry and the people. While increasing the inter-governmental cooperation and dialogue, we can also draw on the wisdom of academia and industry to enhance cooperation and exchanges at all levels. By supporting academic institutions, cultural enterprises, social groups and experts and scholars to carry out extensive cultural exchanges, the resources and advantages of the Fair can be fully displayed [5].

\subsection{The Big Data Expo is conducive to the promotion of regional comprehensive competitiveness}

- The economic development of Guiyang convention and exhibition industry depends highly on the economic development level of Guiyang and surrounding areas. The economic level of Guiyang's exhibition industry and exhibition industry further reflects the industrial base, market capacity, trade function, overall consumption level and tourism characteristics of Guiyang and related areas, and finally reflects the overall economic strength and industrial structure development trend of Guiyang. The Big Data Expo, held in Guiyang, can send concentrated and intuitive signals in the market. According to these 
signals, enterprises adjust their development plans and industrial guidance, which not only realize their own optimization and upgrading, but also promote the development of regional economy. Through the holding of Guiyang Big Data Expo, the functions of the region where it is located as a trade service center and a science and technology financial center have been continuously enhanced. As a whole, the regional functions have been improved and the regional absorption capacity of economic factors and market radiation capacity of the surrounding region have been enhanced. The comprehensive strength of the region has been steadily improved and its competitiveness has been improved.

- The Big Data Expo promotes international cultural exchanges and cooperation, and promotes the improvement of international cooperation mechanisms. In line with the trend of economic globalization, the development of exhibition industry and exhibition economy is conducive to deepening mutual understanding, division of labor and cooperation among different countries and regions, and providing unified market rules, economic order and international practices for the establishment of a complete market system [6]. In China, the convention and exhibition industry has become an important platform for building a modern market system and an open economic system. Although located in southwest China, the successful holding of the Big Data Expo will provide strong support for accelerating the pace of open economic construction in Guiyang and Guizhou and leading and driving the improvement of regional economic internationalization level.

- The Big Data Expo will promote inter-regional economic opening and cooperation and exchange. The Expo will not only promote exchanges and cooperation at the international level, but also promote inter-regional exchanges. After China's reform and opening up, the development level of conference and exhibition industry in coastal areas is obviously higher than that in western areas. The Big Data Expo is a platform for big data exchange and cooperation. A series of exhibitions and seminars will also promote the communication and exchange between southwest China, central China and eastern China to realize mutual learning and common improvement among regions. Openness and cross-regional exhibition industry and exhibition economy is one of the outstanding characteristics. Large-scale communication and interaction promoted by the conference and exhibition industry and the exhibition economy can provide support for the maximization of regional economic benefits.

\section{Conclusion}

As mentioned above, it is obvious that the conference and exhibition industry and exhibition economy play a driving role in regional economic development. The holding and series of activities of the Big Data Expo also provide research cases for the accelerated development of the conference and exhibition industry and exhibition economy in economically underdeveloped areas. Since 2015, Guiyang has successfully held five sessions, forming a certain brand influence and international influence. Remarkable achievements have been made in the fields of politics, economy, culture, science and technology, made positive contributions to the construction of "One Belt And One Road" and national big data construction. In order to strengthen the promotion effect of promoting regional industrial structure optimization and upgrading and then regional economic development through the Big Data Expo, the following three aspects should be considered.

Firstly, further achieve the Big Data Expo brand development and green development. Environmental protection, simplicity and efficiency are the trend and inevitable trend of the development of exhibition industry and exhibition economy in the world today. The advantages and constraints of oasis economy are also an important part of the Big Data Expo. We should pay attention to the number of fair forward-looking and predictability, from the main differences, the operation of the convention and exhibition standardization and other aspects, with the characteristics of the southwest exhibition industry and exhibition economy for accurate positioning and continuous practice. At the same time, we will further expand the publicity and promotion of the Digital Expo and other important exhibitions in Guizhou, realize the branding and development of the conference and exhibition industry in Guizhou, improve the visibility and radiation scope of the conference and exhibition brand in Guizhou, and conform to the green trend of international conferences and exhibitions.

Secondly, further improve the operation mechanism of the Digital Expo, improve the quality of the Big Data Expo. Due to location restrictions and backward economic development, few national and international exhibitions have been undertaken by Guizhou in the past, so the influence and radiation scope of the Big Data Expo are still far behind those of the regions with developed exhibition economy. In order to activate the development power of digital expo, the operation mechanism of the Big Data Expo should pay attention to the combination of government leading and market forces. The first Big Data Expo in 2015 is characterized by government leadership. In the future, the operation of the Big Data Expo should consider more market mechanism and fully mobilize all social forces to promote the vigorous development of the exhibition industry and exhibition economy.

Thirdly, it will substantively promote international and regional cooperation in the Big Data Expo. The expo will not only take the initiative to carry out exchanges in the fields of culture, education and tourism with neighboring countries and regions, but also deepen extensive cooperation with ministries and commissions sponsored and supported by the country and provinces and municipalities along the "One Belt And One Road", especially along the silk road economic belt. Under the guidance of the national development policy, rich cultural 
resources of Guizhou can be promoted to the world, big data industry can be promoted to the world, regional economic strength can be enhanced, and economic globalization can be integrated into the development posture of open economy and export-oriented economy.

\section{References}

1. Wang Qijing,Gao, Lingjiang, "Integration mechanism and Countermeasures of exhibition industry and tourism industry," China Economic and Trade Guide,2013,29,p. 51 - 52.

2. Wu Kaijun.,"Analysis of tourism enterprises and exhibition enterprises strategic alliance governance mechanism." J. Journal of Beijing International Studies University,2015,5,p. $73-78$.

3. Zhao Xuetong,"The effect of exhibition industry on urban development - a case study of Chongqing,"J. Dissemination and Copyright,2015,8,p.177-178.

4. Zhang Cuijuan, "Research on the influence of exhibition industry on regional economic development,"J. Academic communication, 2014, 05, p. 89-92.

5. Zhang Qin,Chu Deping," Research trend of Mice tourism in China in recent 15 years," J. Tourism research,2016,3,p.35-43.

6. Wang Lisha,"Analysis of the promoting effect of exhibition economy on regional economic developmen,"J.Economic and trade practice, 201511. 